\title{
Efficacy of Integrated Straw Formulations on Lowland Rice Field Organic Carbon and Greenhouse Gas Emissions Using CCAFS-MOT Model in Niger State, Nigeria
}

\author{
Y. S. Koglo ${ }^{1^{*}}$, A. Abdulkadir ${ }^{2}$, D. Feliciano ${ }^{3}$ and A. A. Okhimamhe ${ }^{1}$ \\ ${ }^{1}$ WASCAL CC \& ALU, Federal University of Technology, Minna, Nigeria. \\ ${ }^{2}$ Department of Geography, Federal University of Technology, Minna, Niger State, Nigeria. \\ ${ }^{3}$ Institute of Biological and Environmental Sciences, School of Biological Sciences, \\ University of Aberdeen, Scotland.
}

Authors' contributions

This work was carried out in collaboration between four authors. Author YSK wrote the protocol, designed the study, implemented, monitored, collected experiment data, performed laboratories and statistical analyses, and wrote the manuscript drafts. Author AA corrected, reviewed research protocol and the manuscript draft. Author DF provided CCAFS-MOT model, took part in the model tutorial, results discussion and drafts corrections, and finally author $A A O$ took part in the project proposal, literature and drafts review. All authors read and approved the final manuscript.

Article Information

DOI: 10.9734/AJEA/2016/27088

Editor(s):

(1) Wafaa Haggag, Plant Pathology Department, Agriculture and Biology Research Division, Egypt.

Reviewers:

(1) Yang Yu, China Institute of Water Resource and Hydropower Research, China. (2) F.U. Jingying, Institute of Geographical Sciences and Natural Resources Research, Chinese Academy of Sciences, China. Complete Peer review History: http://www.sciencedomain.org/review-history/15779

Original Research Article

Received $18^{\text {th }}$ May 2016

Accepted $25^{\text {th }}$ June 2016

Published $13^{\text {th }}$ August 2016

\section{ABSTRACT}

Aims: This study aims to determine the short term effects during off-season of pre-wetted straw and urea incorporation on lowland rice field soil carbon sequestration and greenhouse gas emissions using climate change adaptation food security mitigation option tool (CCAFS-MOT) model.

Study Design: The experiment was performed using a Randomized Complete Block Design.

Place and Duration of Study: Nigeria, Niger State, Bida local Government from April to July 2015. 


\begin{abstract}
Methodology: Integrated formulations of rice straw and urea at different rates respectively: 2, 3 and $4 \mathrm{t} / \mathrm{ha}$ and 25, 50 and $75 \mathrm{~kg} / \mathrm{ha}$ were used with one check plot (C) (without straw and urea). The experiment was a Randomized Complete Block Design, and ten (10) integrated formulations (treatments) were used with four (04) replications. Each replication, was made of ten (10) plots giving a total number of forty (40) plots. The effect of treatments on the following variables; Soil Organic Carbon Density Gain per Year (SOCDG/year, kg/ha) and GHGs emissions (kg/ha) were determined in order to identify the best treatments. Data collected were analyzed using GenStat 16.2 and CCAFS-MOT 1.0 for SOC balance. Matlab 11.0 and Excel 2013 were also used for data processing and graphs. Significance and Duncan's Multiple Range Test were performed at $95 \%$.

Results: Results indicated significance difference of treatments on each parameter evaluated. SOCDG increase is function of the quantity of straw and urea incorporated (Fpr. <0.001). Moreover, the study revealed three best treatments (T2, T4 and T5). Their responses (TR, \%) to Soil Organic Carbon Density Gain per Year (SOCDG/year, kg/ha) have increased up to $43 \%$. Potential carbon sequestration estimated by the CCAFS-MOT was about $44.4 \%$ for the improved practices identified with $0 \%$ methane emission and scanty nitrous oxide emission up to $31.3 \%$. These results give strong evidence concerning the use of pre-wetted technique as panacea to both mitigate climate change and enhance croplands productivity and resilience to these changes in Niger State, Nigeria.

Conclusion: Pre-wetted straw and urea application can help to deplete greenhouse gas emission and enhance carbon on agricultural lands. However, additional trials are needed before validation of the method under different agro ecological conditions in west African zones.
\end{abstract}

Keywords: Pre-wetted technique; integrated formulation; Soil Organic Carbon Density Gain (SOCDG); CCAFS-MOT model; Greenhouse gas (GHG); Lowlands; Niger State; Nigeria.

\section{INTRODUCTION}

The impact of climate change and global warming are worldwide, and an increasing number of evidence in recent years have clearly established the fact that anthropogenic climate change is a reality. According to studies $[1,2,3]$, developing countries are more exposed to experience the negative impacts of climate change owing to their fragile economic sectors and the reliance of many livelihoods on climatesensitive factors. An increase of human activities exacerbates the release of greenhouse gases such as carbon dioxide, methane, nitrous in the atmosphere. According to the fifth report of [2], human activities such as poor agriculture practices, deforestation, fossil burning, and poor land management practices are the main drivers of global warming since the mid-20th century. [4] posited that carbon dioxide is the main greenhouse gas realized in the atmosphere since the past twenty years. [5] in its fourth assessment quoted that $\mathrm{CO}_{2}$ concentration from agricultural practices in the atmosphere has increased from $280 \mu \mathrm{mol} / \mathrm{mol}$ before industry revolution to $379 \mu \mathrm{mol} / \mathrm{mol}$ in 2005 , and it would be increasing by a rate of $1.9 \mu \mathrm{mol} / \mathrm{mol}$ per year. Consequently, agriculture is considered as a main source of $\mathrm{CO}_{2}$ realizing in the atmosphere as well as soil health degradation $[6,7,8,9]$. Thus world agricultural soils are historitically considered as a major source of atmospheric enrichment of carbon dioxide. Though, certain uncertainties dwelled in the statistics, about $80 \%$ of the global emissions presently came from land use change and poor croplands management practices $[2,6,10,11]$. Globally, croplands have the capacity to store $248 \mathrm{Pg}$ of carbon in the top 3 metre of soil, but this proportion is seriously disturbed by land use practices which exacerbate the loss of SOC (Soil Organic Carbon) [12,13]. Nonetheless, agriculture can play an imminent role in removing carbon dioxide from the atmosphere through soil conservation practices commonly named Improved Management Practices (IMPs) techniques which, permit to enhance soil organic matter storage with minimum soil disturbance through management of farming systems [13,14,15]. Accordingly, implementation of judicious mulching tillage combined with fertilizers applications, cover crops, hedgegrow intercropping (alley farming), less or no tillage and other Sustainable Agricultural Land Management Practices (SALMP) are options that can help to maintain, control, monitor and enhance croplands resilience under climate change, and deplete soil carbon losses and therefore mitigate greenhouse emission in the atmosphere $[12,16,17]$.

Nigeria in general and Niger State in particular, is considered as one of the major pole of rice 
production and consumption in West Africa. Rice cultivation is mainly rainfed with predominant of lowlands systems [18]. For instance, in Niger state upland rice, lowland (without water management) and irrigated (with lowland management) accounts respectively for $0 \%, 95 \%$ and $30 \%$ of total area under rice cultivation. And, similarly to other African countries and villages, one of the most vulnerable to climate change owing to poverty, dominance of rainfed agriculture and poor soil management practices $[1,19,20]$. [21] quoted that, Niger State rice growers encountered a veritable problem in the management of rice straw and they are constraint to burn these residues, that is, increase emission of greenhouse gases in the atmosphere. Some of barriers that limit straws residue incorporation into the soil are their feeding interests (use as forage in livestock), lack for practical knowledge, and financial resources needed for straw management and incorporation. Moreover, agricultural lands in that area are experiencing a decline in fertility due to their overuse and mismanagement which, is likely to generate and enhance carbon losses from these exposed and vulnerable arable lands thus, increase carbon dioxide emission into the atmosphere $[19,21,22]$.These straw can be used as biological fertilizer in combination with urea in order to enhance soil organic carbon pool, its fertility under climate negative effects on croplands also co-benefits yield in agriculture productivity in degraded zones [23,24]. Moreover, no study has been conducted in the area over short the period concerning the use of pre-wetted techniques as new sustainable agricultural land management approach for soil organic carbon sequestration and greenhouse gas emissions reduction from practices used on arable lands under cultivation $[22,25,26]$. These vacuums underscore the relevance of this study, through which innovative, available, accessible and cost effect land management approach will be experimented for introduction and dissemination in that locality, and empower Niger State, Nigeria smallholder's adaptation, coping and mitigation strategies to climate change through both enhancement of soil organic carbon pool subsequently reduce greenhouse gas emissions from agricultural lands.

Objectives of this study were (i) to compute monthly soil organic carbon density gain (SOCDG) under each pre-wetted integrated technique, (ii) to determine yearly greenhouse gas emission from each treatment, and (iii) to identify the best pre-wetted techniques with significant yearly SOCDG, carbon sequestration potential with scanty methane $\left(\mathrm{CH}_{4}\right)$ and nitrous oxide emissions $\left(\mathrm{N}_{2} \mathrm{O}\right)$.

\section{MATERIALS AND METHODS}

\subsection{Experiment Site and Design}

This study was conducted at Edozhigi, Niger State, Nigeria. It lies between Longitude $5^{\circ} 46^{\top}$ to $6^{\circ} 03^{1} \mathrm{E}$ and Latitude $8^{\circ} 25^{1}$ to $9^{\circ} 13^{1} \mathrm{~N}$ (Fig. 1) at 12 kilometre northwards Bida town. Estimated population is about 150,640 inhabitants and more than $70 \%$ of the villagers are totally involved in rainfed agriculture as main revenue source [25].

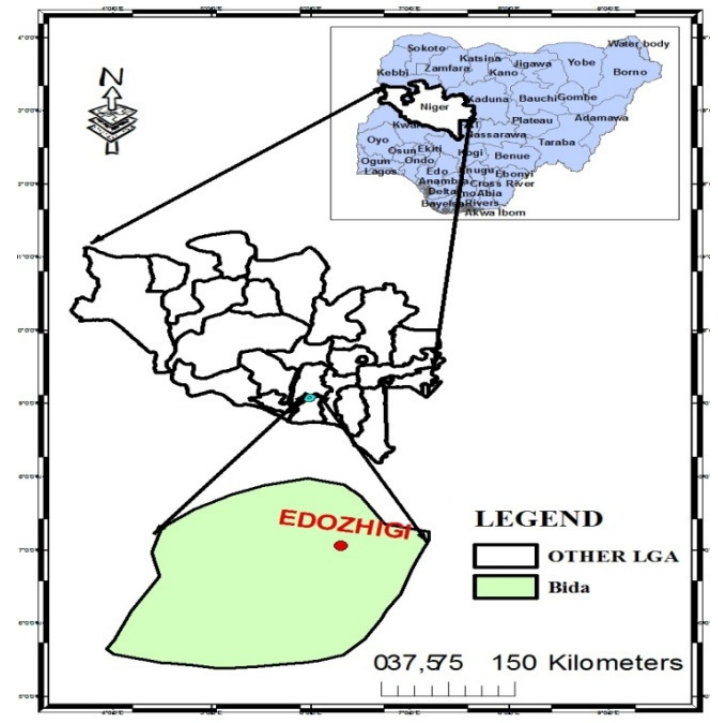

Fig. 1. Study area

Edozhigi, serves as a market centre for mainly rice followed by sorghum, yams, millet, groundnuts and cotton. It experiences two spells of season namely rainy and dry season respectively from April to October and November to March. Annual average of rainfall is up to $1,600 \mathrm{~mm}$ with an average maximum temperature up to about $32^{\circ} \mathrm{C}$ [22]. In terms of soils patterns, ferruginous tropical soils are predominant. Most of the soils in the area are poorly drained. Land use pressure and inadequate soil practices on the fragile soils exposed most of them to erosion and an exacerbate depletion of soil nutrients [26]. The experiment was a Randomized Complete Block Design, and ten (10) integrated formulations (treatments) were used with four (04) replications. Each replication, was made of ten 
(10) plots giving a total number of forty (40) plots. Each plot measured $2 \mathrm{mx} 2 \mathrm{~m}$. Experiment design occupied $406 \mathrm{~m}^{2}$ as total surface but $160 \mathrm{~m}^{2}$ as useful surface excluding borders, space between plots and alley between blocks. Space within plots and between replications was respectively $1 \mathrm{~m}$ and $2 \mathrm{~m}$. Integrated formulations (Treatments) were disposed randomly in each block, and each treatment was replicated once within each block including the witness.

\subsubsection{Integrated formulations}

This experiment was conducted with integrated formulations (treatments) of rice straw and urea at different rates respectively 2,3 and $4 \mathrm{t} / \mathrm{ha}$ and 25,50 and $75 \mathrm{~kg} / \mathrm{ha}$; couple with one control (C) without straw and urea application (check plot). Nine treatments were generated from the formulation. $0 \mathrm{~S}+0 \mathrm{~F}$ stands for 0 ton of straw (S) and 0 kilogram of fertilizer (F); $3 S+50 F$ stands for 3t of straw and $50 \mathrm{~kg}$ of Fertilizer as graded in Table 1a. Each treatment on the field was watered at equal amount of water (1.5 liters) on fifteen days interval.

Table 1a. List of the integrated formulations

\begin{tabular}{lll}
\hline No & $\begin{array}{l}\text { Treatment } \\
\text { (xt/haS+ykg/haF) }\end{array}$ & $\begin{array}{l}\text { Treatment } \\
\text { code }\end{array}$ \\
\hline 1 & $0 \mathrm{~S}+0 \mathrm{~F}$ & $\mathrm{C}$ \\
2 & $3 \mathrm{~S}+50 \mathrm{~F}$ & $\mathrm{~T} 1$ \\
3 & $4 \mathrm{~S}+50 \mathrm{~F}$ & $\mathrm{~T} 2$ \\
4 & $2 \mathrm{~S}+75 \mathrm{~F}$ & $\mathrm{~T} 3$ \\
5 & $4 \mathrm{~S}+75 \mathrm{~F}$ & $\mathrm{~T} 4$ \\
6 & $4 \mathrm{~S}+25 \mathrm{~F}$ & $\mathrm{~T} 5$ \\
7 & $2 \mathrm{~S}+25 \mathrm{~F}$ & $\mathrm{~T} 6$ \\
8 & $2 \mathrm{~S}+50 \mathrm{~F}$ & $\mathrm{~T} 7$ \\
9 & $3 \mathrm{~S}+75 \mathrm{~F}$ & $\mathrm{~T} 8$ \\
10 & $3 \mathrm{~S}+25 \mathrm{~F}$ & $\mathrm{~T} 9$ \\
\hline \multicolumn{3}{c}{ S: Rice straw; F: Fertilizer (Urea), C: Control, } \\
\multicolumn{4}{c}{ XS $+Y F(X=$ quantity of straw in t/ha; } \\
\multicolumn{4}{c}{$Y=q u a n t i t y$ of urea in $\mathrm{kg} / \mathrm{ha})$}
\end{tabular}

\subsubsection{Pre-wetted technique implementation and trial management}

For our integrated land management approach (Pre-wetted technique), both incorporation of straw and urea on each corresponding plot was not direct. The straw of each treatment was wetted first with equal and minimum volume of water (1.5 litre) and then covered with small empty tilts of $50 \mathrm{~kg}$ during seven (07) days at ambient temperature condition. After seven days, lump quantity of urea was broadcast based on the rate of each treatment (Table 1a) and each treatment was covered again with the same tilts for the same period of seven Days before Plotting (DBP). On the fifteen Day of Plotting (DOP: 15-03-2015), each pre-wetted treatment was now incorporated on each plot using hoes. In addition, hoes were used to mix-up soil surface with the incorporated application on each plot for each replication without soil disturbance. Thereafter, an additional quantity of water (1.5litre/plot) was added after fifteen Days after Plotting (DAP). Trial was monitored, managed and different data were collected over a period of three months from $15^{\text {th }}$ March to $15^{\text {th }}$ June 2015. Data were collected based on documentation and experimentation requirements. Data were analysed using GenStat2010, Excel2013 and Matlab 11.0. Treatments means were discriminated using Duncan's Multiple Range Test at 95 percent confidence level.

\subsection{Data Collection Procedure}

\subsubsection{Soil organic carbon density (SOCD, t/ha)}

Wet chemical oxidation method $[27,28,29]$ was adopted to determine SOC concentration in percentage (\%) which was used to compute the density (dose). Composite soils of each treatment were sampled for determining SOC concentration after three months. For bulk density determination, soil samples were collected from all plots from 0 to 5 and 5 to $15 \mathrm{~cm}$ depths. Samples were collected by using a core sampler of $5.5 \mathrm{~cm}$ diameter and $4 \mathrm{~cm}$ long cores from $0-5 \mathrm{~cm}$ and $6 \mathrm{~cm}$ long cores from $5-15 \mathrm{~cm}$. The dry bulk density was computed for each plot by using the oven dried method. The dry weight of soil was obtained by oven drying it at $105^{\circ} \mathrm{C}$ for 48 hours until the constant weight obtained. The dry bulk density was computed using the following equation:

$$
\operatorname{BD}\left(\frac{\mathrm{g}}{\mathrm{cm}^{3}}\right)=\frac{\mathrm{M}_{\mathrm{s}}}{\mathrm{V}_{\mathrm{t}}}
$$

Where BD stands for dry bulk density; $\mathrm{M}_{\mathrm{s}}$ for mass of oven dried soil at $105^{\circ} \mathrm{C}$ and $\mathrm{V}_{t}$ the volume of each core (total volume of soil of each core). Thus, knowing the dry bulk density, the density (dose) of soil organic carbon under each treatment was determined by using the following formula:

$$
\operatorname{SOCD}\left(\frac{\mathrm{t}}{\mathrm{ha}}\right)=\mathrm{C}_{\mathrm{SOC}} \times \mathrm{BD} \times \mathrm{H}
$$


Where, $\mathrm{C}_{\mathrm{SOC}}, \mathrm{BD}$ and $\mathrm{H}$ are respectively the concentration of soil organic carbon (\%), dry bulk density $\left(\frac{\mathrm{g}}{\mathrm{cm}^{3}}\right)$ and soil thickness $(\mathrm{cm})$.

\subsubsection{Soil organic carbon density gain per month (SOCDG, t/ha)}

Knowing the density of soil organic carbon of each treatment, the gain $(\Delta D)$ of each treatment in organic carbon in the soil per month was determined using the modified formula [30] defines as:

$$
\Delta \mathrm{D}\left(\frac{\frac{\mathrm{t}}{\mathrm{ha}}}{\text { month }}\right)=\frac{\operatorname{SOCD}_{\mathrm{f}}-\left(\mathrm{SOCD}_{\mathrm{cf}}-\operatorname{SOCD}_{\mathrm{ci}}\right)}{\text { time }}
$$

Where $\mathrm{SOCD}_{\mathrm{f}}, \mathrm{SOCD}_{\mathrm{cf}}$ and $\mathrm{SOCD}_{\mathrm{ci}}$ are respectively the density of soil organic carbon of last month for each treatment and last and first month of the check plot. Composite soils were sampled at the two depths during the trial installation after soil preparation for determining $\mathrm{SOCD}_{\mathrm{ci}}$.

\subsubsection{Greenhouse gas $\left(\mathrm{CO}_{2}, \mathrm{CH}_{4}\right.$ and $\left.\mathrm{N}_{2} \mathrm{O}\right)$ emissions from lands and treatments}

GHGs were determined using CCAFS-MOT (Climate Change Adaptation Food Security Mitigation Option Tool) model developed by University of Aberdeen in partnership with CCAFS and the University of Vermont's Gund Institute for Ecological Economics ${ }^{1}$. Therefore, model input data such as: region (country, climate type and soil type) and treatments information (experiment duration, land management, quantity of straw and urea input for each treatment) were used to run the model. Soil type information which included: soil texture, organic $\mathrm{C}(\%)$, nitrogen content $\mathrm{N}(\%)$, soil $\mathrm{pH}$ and bulk density $\left(\mathrm{g} / \mathrm{cm}^{3}\right)$ were determined through laboratory analysis of the sampled soil of the study area before trial installation. Soil core sampler was used to sample the soil from $0-15$ $\mathrm{cm}$.

\subsubsection{Identification of best treatments}

Identification of best treatments was based on the mean value of SOC dose, soil temperature

\footnotetext{
${ }^{1}$ https://ccafs.cgiar.org/mitigation-option-toolagriculture\#.Vw9dBTL2apo
}

and soil moisture computed. Treatments were now ranked based on the amount of soil organic carbon density to determine best treatments in terms of significant SOCDG stored per year, SOC balance, methane and nitrous oxide emission. Treatments response in percentage (TR, \%) was determined with the following mathematical expression:

$$
\mathrm{TR}_{\mathrm{vi}}=\frac{\mathrm{V}_{\mathrm{vi}}}{\sum_{\mathrm{n}=10}^{\mathrm{n}} \mathrm{T}} \times 100
$$

With, $\mathrm{TR}_{\mathrm{vi}}$ standing for treatment response to variable $\mathrm{i}(\%), \mathrm{V}_{\mathrm{vi}}$ for variable value of treatment $\mathrm{i}$ $\left(\%,{ }^{\circ} \mathrm{C}, \mathrm{kg} / \mathrm{ha}\right.$ or $\left.\mathrm{t} / \mathrm{ha}\right)$ and $\sum_{\mathrm{n}=10}^{\mathrm{n}} \mathrm{T}$ for total value of treatment for the variable $\mathrm{i}\left(\%,{ }^{\circ} \mathrm{C}, \mathrm{kg} / \mathrm{ha}\right.$ or $\left.\mathrm{t} / \mathrm{ha}\right)$.

\section{RESULTS AND DISCUSSION}

\subsection{SOCD Gain per Month (SOCDG, t/ha)}

Results graded in Table $1 \mathrm{~b}$ reveal small dispersion between treatments in terms of carbon gained per month. Generally, amount stored per month differs from one treatment to another however the quantity was not too high between treatments from $0-15 \mathrm{~cm}$.

Mean monthly storage ( $\mathrm{t} / \mathrm{ha} / \mathrm{month} \mathrm{y}$ ) varies from $0.05-0.15$ with maximum and minimum range between $0.08-0.23$ and $0.01-0.16$ respectively with standard deviation between $0.01-0.06$ at 5 $\mathrm{cm}$. At $15 \mathrm{~cm}$, mean of SOCDG ranges between $0.09-0.38$ with maximum and minimum ranging from $0.11-0.45$ and $0.05-0.31$ respectively. Standard deviation is between $0.03-0.11$ at 15 $\mathrm{cm}$. Treatments (Table 2) demonstrated very significant effects on soil organic carbon gain (SOCDG, kg/ha/month) from $0-15 \mathrm{~cm}$. The Least Significance Difference varies between $19.0(0-5 \mathrm{~cm})$ and $20.3(5-15 \mathrm{~cm})(\mathrm{Fpr} .<0.001)$. Treatments evaluated indicate better contribution in terms of monthly carbon pool compared to the check plot which, has the lowest $(0.052-0.085)$ monthly carbon pool after the three months experiment.

In general (Table 2), treatments net addition in carbon ( $\mathrm{t} / \mathrm{ha}$ ) per month vary from $0.05-0.2$ between $0-5 \mathrm{~cm}$ and $0.09-0.4$ between $5-$ $15 \mathrm{~cm}$. Based on the depth variation between $0-$ $5 \mathrm{~cm}$, highest significance difference on SOCDG 
Table 1b. Statistical summary of soil organic carbon gain per month ( $t / \mathrm{ha} / \mathrm{month}$ )

\begin{tabular}{|c|c|c|c|c|c|c|c|c|c|}
\hline \multirow[t]{2}{*}{ Depth (cm) } & & \multicolumn{7}{|c|}{$\begin{array}{l}\text { Gain per month of organic carbon (t/ha/month) under each } \\
\text { treatment }\end{array}$} & \multirow[b]{3}{*}{ Stdev. } \\
\hline & & \multicolumn{4}{|c|}{$0-5$} & \multicolumn{3}{|c|}{$5-15$} & \\
\hline Treatment & Code & Mean & Max & Min & Stdev. & Mean & Max & Min & \\
\hline $0 \mathrm{~S}+0 \mathrm{~F}$ & $\mathrm{C}$ & 0.05 & 0.08 & 0.01 & 0.03 & 0.09 & 0.11 & 0.05 & 0.03 \\
\hline $3 S+50 F$ & T1 & 0.09 & 0.11 & 0.07 & 0.02 & 0.18 & 0.23 & 0.14 & 0.04 \\
\hline $4 \mathrm{~S}+50 \mathrm{~F}$ & T2 & 0.15 & 0.23 & 0.09 & 0.06 & 0.30 & 0.45 & 0.17 & 0.11 \\
\hline $2 \mathrm{~S}+75 \mathrm{~F}$ & T3 & 0.11 & 0.12 & 0.09 & 0.01 & 0.21 & 0.23 & 0.17 & 0.03 \\
\hline $4 S+75 F$ & T4 & 0.19 & 0.21 & 0.16 & 0.02 & 0.38 & 0.45 & 0.31 & 0.06 \\
\hline $4 \mathrm{~S}+25 \mathrm{~F}$ & T5 & 0.12 & 0.18 & 0.08 & 0.04 & 0.22 & 0.37 & 0.13 & 0.10 \\
\hline $2 \mathrm{~S}+25 \mathrm{~F}$ & T6 & 0.10 & 0.12 & 0.09 & 0.02 & 0.18 & 0.23 & 0.15 & 0.04 \\
\hline $2 \mathrm{~S}+50 \mathrm{~F}$ & T7 & 0.08 & 0.10 & 0.04 & 0.03 & 0.15 & 0.20 & 0.07 & 0.06 \\
\hline $3 S+75 F$ & T8 & 0.10 & 0.12 & 0.08 & 0.02 & 0.18 & 0.23 & 0.15 & 0.04 \\
\hline $3 S+25 F$ & T9 & 0.10 & 0.14 & 0.07 & 0.03 & 0.19 & 0.28 & 0.14 & 0.06 \\
\hline
\end{tabular}

Table 2. Effect of treatments on soil carbon gain per month at various depth

\begin{tabular}{|c|c|c|c|c|}
\hline \multirow{3}{*}{ Treatment } & & & \multicolumn{2}{|r|}{ Depth (cm) } \\
\hline & & & $0-5 \mathrm{~cm}$ & $5-15 \mathrm{~cm}$ \\
\hline & & & \multicolumn{2}{|c|}{ SOCG (t/ha/month) mean significant value } \\
\hline & T4 & $4 \mathrm{~S}+75 \mathrm{~F}$ & $0.2 \mathrm{a}$ & $0.4 \mathrm{a}$ \\
\hline & T2 & $4 \mathrm{~S}+50 \mathrm{~F}$ & $0.15 b$ & $0.3 \mathrm{~b}$ \\
\hline & T1 & $3 \mathrm{~S}+50 \mathrm{~F}$ & $0.1 \mathrm{c}$ & $0.2 \mathrm{c}$ \\
\hline \multirow[t]{9}{*}{ Straw + Urea } & T3 & $2 \mathrm{~S}+75 \mathrm{~F}$ & $0.1 \mathrm{c}$ & $0.2 \mathrm{c}$ \\
\hline & T5 & $4 S+25 F$ & $0.1 \mathrm{c}$ & $0.2 \mathrm{c}$ \\
\hline & T6 & $2 \mathrm{~S}+25 \mathrm{~F}$ & $0.1 \mathrm{c}$ & $0.2 \mathrm{c}$ \\
\hline & T7 & $2 \mathrm{~S}+50 \mathrm{~F}$ & $0.1 \mathrm{c}$ & $0.2 \mathrm{c}$ \\
\hline & T8 & $3 \mathrm{~S}+75 \mathrm{~F}$ & $0.1 \mathrm{c}$ & $0.2 \mathrm{c}$ \\
\hline & T9 & $3 S+25 F$ & $0.1 \mathrm{c}$ & $0.2 \mathrm{c}$ \\
\hline & C & $\mathrm{OS}+\mathrm{OF}$ & $0.05 d$ & $0.09 \mathrm{~d}$ \\
\hline & C.V. (\%) & & 19.0 & 20.3 \\
\hline & Isd & & 0.04 & 0.07 \\
\hline \multicolumn{3}{|c|}{ Mean ( $\mathrm{t} / \mathrm{ha} /$ month) } & $0.1( \pm 0.01)$ & $0.2( \pm 0.03)$ \\
\hline
\end{tabular}
(DMRT at 5\%)

(t/ha/month) was obtained with T4 followed by T2 then, T1, T3, T5, T6, T7, T8 and T9 which have the same level of significance on carbon input but significant when compared to the control effect on carbon gain per month. Similarly, between $5-15 \mathrm{~cm}$, the highest input in carbon was obtained with T4 (0.4) followed by T2 (0.3) and a set of treatments T1, T3, T5, T6, T7, T8 and T9 with the same significance on carbon input but significantly different from the control $\mathrm{C}$ in terms of soil carbon gained per month. Results from this short-term experiment, coincide with [31] on the effects of time on improved management practices carbon sequestration. In fact, carbon input from crop residues duration is synonymous with the time to which soil carbon steady state is reached. In addition, this sequestration is not finite but will get to saturation point after certain periods [32,33]. That is the reason why it is paramount to identify the practice that can enhance carbon pool within a short period of time in order to know the finite limit of soil in carbon sequestration for implementation of adaptation and mitigation policies.

\subsection{Greenhouse Gas $\left(\mathrm{CO}_{2}, \mathrm{CH}_{4}\right.$ and $\left.\mathrm{N}_{2} \mathrm{O}\right)$ Emissions}

Climate Change Adaptation Food Security Mitigation Option Tool (CCAFS-MOT) model analysis (Table 3 ) indicates significant variation in terms of greenhouse gas (GHG) emissions from the field under each treatment and the Soil Organic Carbon (SOC) balance significance as a result of the pre-wetted technique. For the SOC balance, negative values stand for sequestration whereas, positive values indicate emission from 
the pre-wetted integrated formulations. The standard deviation for SOC balance (Stdev = $324.6 \mathrm{~kg} / \mathrm{ha} /$ year) in Table 3 indicates large dispersion of carbon added to the soil by each treatment when compared to the control plot where no addition of carbon is recorded $(0$ $\mathrm{kg} / \mathrm{ha}$ ). Methane emission is zero for all treatments comprised the control but scanty emission of nitrous oxide can be observed from 0.1-0.2 kg/ha/year with non-significant dispersion (Stdev. $=0.05 \mathrm{~kg} / \mathrm{ha} /$ year).

The risk of avoiding emission or enhancing carbon sequestration was higher under T2, T4 and T5 with a carbon balance up to -1037.5 $\mathrm{kg} / \mathrm{ha}$; followed by T1, T8 and T9 $(-778.1 \mathrm{~kg} / \mathrm{ha})$ and finally T3, T6 and T5 $(-518.8 \mathrm{~kg} / \mathrm{ha})$. These results draw our attention on the fact that soil organic carbon pool enhancement is likely a function of the amount of residues incorporated into the soil. Simply put, soil organic carbon increases with an increase of crop residues into the soil. However other factors such as soil type, climatic and farmer's practices and nutrients application can also be considered. In fact, [23] and [34] also highlighted the significance effects of climate, soil factors and land management practices on agricultural lands soil organic carbon pool enhancement. Aforementioned results are indicating that, treatments $\mathrm{T} 2, \mathrm{~T} 4$, and T5 can be promoted in order to increase soil carbon pools knowing that, for every ton of carbon sequestered in the soil is a ton of carbon removed from the atmosphere, and every ton of carbon in the soil is equivalent to 3.67 ton of $\mathrm{CO}_{2}$ $[9,35]$. In contrast, no carbon addition was observed with the control (0 kg/ha). Similarly, [36] and [37] have also quoted lower emissions of $\mathrm{CO}_{2}$ under mulching plots compared to unmulching plots. Indeed, carbon dioxide fluxes under straw mulching or crop residues are due to slow decomposition of crop residues placed on the surface of the soil compared to residues incorporated under conventional tillage [36]. Moreover, high carbon sequestration under T2, T4 and T5 can be correlated to their likely high soil moisture content. Otherwise, there is a negative correlation between $\mathrm{CO}_{2}$ fluxes and soil moisture content. This negative relationship was also highlighted by [38] and [39]. As we can observe, carbon sequestration into soil mainly agricultural lands, plays an important role in mitigating to climate change. By enhancing the carbon pool, we are limiting its emission into the atmosphere. Moreover, we are increasing soil physical, biological and chemical properties in terms of water retention and $\mathrm{pH}$ moderation for plants growth; fertility enhancement subsequently increase in food supply for smallholders and poorest people whom relied on rainfed agricultural activities as main source of revenue $[13,15]$.

In contrast, no methane $\left(\mathrm{CH}_{4}\right)$ emissions associated to the addition of straw were observed both from the treatment and the control. Those outcomes are in accordance with previous studies done which had stated that there is no correlation between $\mathrm{CH} 4$ fluxes and soil moisture, but sometimes these fluxes are negatively correlated with soil temperature $[39,40]$. In fact, scanty information exists

Table 3. CCAFS-MOT estimated GHGs and SOC balance in $\mathrm{Kg} / \mathrm{ha} / \mathrm{year}$

\begin{tabular}{|c|c|c|c|c|}
\hline \multirow[t]{2}{*}{ Treatment } & \multirow[t]{2}{*}{ Code } & \multirow[t]{2}{*}{ SOC Balance } & \multicolumn{2}{|c|}{$\begin{array}{l}\text { GHGs emissions from field and rice straw } \\
\text { management }(\mathrm{Kg} / \mathrm{ha})\end{array}$} \\
\hline & & & $\mathrm{CH}_{4}$ & $\mathrm{~N}_{2} \mathrm{O}$ \\
\hline $\mathrm{OS}+\mathrm{OF}$ & $\mathrm{C}$ & 0 & 0 & 0.1 \\
\hline $3 S+50 F$ & T1 & -778.1 & 0 & 0.2 \\
\hline $4 S+50 F$ & T2 & -1037.5 & 0 & 0.2 \\
\hline $2 S+75 F$ & T3 & -518.8 & 0 & 0.2 \\
\hline $4 S+75 F$ & T4 & -1037.5 & 0 & 0.2 \\
\hline $4 S+25 F$ & T5 & -1037.5 & 0 & 0.1 \\
\hline $2 S+25 F$ & T6 & -518.8 & 0 & 0.1 \\
\hline $2 S+50 F$ & T7 & -518.8 & 0 & 0.2 \\
\hline $3 S+75 F$ & T8 & -778.1 & 0 & 0.2 \\
\hline $3 S+25 F$ & T9 & -778.1 & 0 & 0.1 \\
\hline Mean $(\mathrm{kg} / \mathrm{ha})$ & & $-700.32( \pm 102.7)$ & 0 & $0.16( \pm 0.02)$ \\
\hline Stdev. $(\mathrm{kg} / \mathrm{ha})$ & & 324.6 & 0 & 0.05 \\
\hline C.V. $(\%)$ & & -0.46 & 0 & 0.32 \\
\hline
\end{tabular}

S: rice straw (t/ha); F: urea (kg/ha); C: control; T: treatment; SOC: Soil Organic Carbon Balance (negative values: sinks or sequestration and positive values: emissions or release); $\mathrm{CH}_{4}$ : methane; $\mathrm{N}_{2} \mathrm{O}$ : Nitrous oxide; GHGs: greenhouse gases; Stdev: standard deviation from the mean 
concerning methane emissions from agricultural practices either mulching tillage or conventional tillage. Meanwhile, [41,42] have clarified the fact that, lower $\mathrm{CH}_{4}$ fluxes under mulching plots compared to bare plots are likely due to significant $\mathrm{CH}_{4}$ oxidation under straw mulching practices causing then a negative fluxes that are sometimes observed. That absence of emission can also be attributed to the water regime that was predominant during the experiment. The experiment was conducted off season with absence of water. The amount supplied was that of the treatment equivalent. The time of experiment and the amount of straw and nutrient applied also determined the amount of methane being realized. Couple to that, the time of the experiment does not favored methanogens and methanotrophs development respectively responsible for methane production and oxidation. It is likely that, minimum of water applied under not rain condition, absence of additional supply in organic amendments underscore the total absence of $\mathrm{CH}_{4}$ fluxes during the off season integrated formulations incorporation. These results are consistent with $[43,44]$ research outcomes. In fact, results from their study had shown that, methane fluxes from rice field is a combined effect of the water regime, soil properties, climate, crop management and the cropping season. These findings are in common accordance with the model results in the way that, no rice was planted during the experiment and the experiment was not flooded too.

Concern the nitrous oxide $\left(\mathrm{N}_{2} \mathrm{O}\right)$ fluxes, tiny fluxes $(0.1-0.2 \mathrm{~kg} / \mathrm{ha})$ were recorded from both treatments and control plots. This study comes to confirm the scarce information and the misunderstanding in terms of $\mathrm{N}_{2} \mathrm{O}$ emissions under combined application of straw mulching and fertilizers [45]. Some stand for negative correlation whereas some quoted higher emission under mulching and fertilizer uses $[40,45,46]$. According to [47], straw application can decrease nitrous oxide $\left(\mathrm{N}_{2} \mathrm{O}\right)$ emission by 1 - $7 \%$ compared to bare soils. In contrast, $[48,49]$ quoted that, the amount of $\mathrm{N}_{2} \mathrm{O}$ emitted is function of type of fertilizer used, method of broadcasting, soil moisture content, soil temperature and amount of oxygen available in the study area.

\subsection{Identification of Best Treatments}

In respect to the summary Table (Table 4) soil organic carbon density gained per year (SOCDG/year) is lower under the control plot (822) and higher under T4 (3408). Finally, in terms of greenhouse emissions and soil carbon balance, we observed high potential carbon sequestration under treatment T2, T4 and T5 up to $1037.5 \mathrm{~kg} / \mathrm{ha} /$ year whereas, neither carbon sequestration nor emission was observed with the control C (0 $\mathrm{kg} / \mathrm{ha} /$ year $)$. No methane emission was observed from the analysis for all treatments and the control used. However, nitrous oxide emission was scanty and ranges between $0.1-0.2 \mathrm{~kg} / \mathrm{ha} / \mathrm{year}$. Therefore, best improved practices can be identified from the summary Table 4 . Results from the technique were promising and more valuable in terms of time scale response compare to the existing method used. Three best treatments (T2, T4 and T5) in terms of carbon sequestration and low methane and Nitrous emissions were identified (Table 5), and their responses (TR, \%) were computed.

Soil Organic Carbon Density Gain per year (SOCDG) has increased respectively up to $43 \%$. Potential carbon sequestration was about $44.4 \%$

Table 4. Summary table of treatments versus measured variables in $\mathrm{kg} / \mathrm{ha} / \mathrm{year}$

\begin{tabular}{|c|c|c|c|c|c|}
\hline \multirow[t]{2}{*}{ Treatment } & \multirow[t]{2}{*}{ Code } & \multicolumn{4}{|c|}{ Measured variables } \\
\hline & & SOCDG & SOC B. & $\mathrm{CH}_{4}$ & $\mathrm{~N}_{2} \mathrm{O}$ \\
\hline T4 & $4 \mathrm{~S}+75 \mathrm{~F}$ & 3408 & -1037.5 & 0 & 0.2 \\
\hline T2 & $4 \mathrm{~S}+50 \mathrm{~F}$ & 2670 & -1037.5 & 0 & 0.2 \\
\hline T5 & $4 \mathrm{~S}+25 \mathrm{~F}$ & 2010 & -1037.5 & 0 & 0.1 \\
\hline T3 & $2 \mathrm{~S}+75 \mathrm{~F}$ & 1854 & -518.8 & 0 & 0.2 \\
\hline T9 & $3 S+25 F$ & 1782 & -778.1 & 0 & 0.1 \\
\hline T8 & $3 \mathrm{~S}+75 \mathrm{~F}$ & 1692 & -778.1 & 0 & 0.2 \\
\hline T6 & $2 \mathrm{~S}+25 \mathrm{~F}$ & 1644 & -518.8 & 0 & 0.1 \\
\hline T1 & $3 S+50 F$ & 1602 & -778.1 & 0 & 0.2 \\
\hline T7 & $2 \mathrm{~S}+50 \mathrm{~F}$ & 1374 & -518.8 & 0 & 0.2 \\
\hline C & $0 \mathrm{~S}+0 \mathrm{~F}$ & 822 & 0 & 0 & 0.1 \\
\hline
\end{tabular}


Table 5. Practices identified for SOC enhancement and GHGs depletion in $\mathrm{kg} / \mathrm{ha} / \mathrm{year}$

\begin{tabular}{|c|c|c|c|c|c|}
\hline \multirow[t]{2}{*}{ Treatment } & \multirow[t]{2}{*}{ Code } & \multicolumn{4}{|c|}{ Measured variables } \\
\hline & & SOCDG & SOC Balance & $\mathrm{CH} 4$ & N20 \\
\hline T4 & $4 \mathrm{~S}+75 \mathrm{~F}$ & 3408 & -1037.5 & 0 & 0.2 \\
\hline T2 & $4 S+50 F$ & 2670 & -1037.5 & 0 & 0.2 \\
\hline T5 & $4 \mathrm{~S}+25 \mathrm{~F}$ & 2010 & -1037.5 & 0 & 0.1 \\
\hline \multicolumn{2}{|c|}{ Treatments Response (TR, \%) } & 43 & 44.4 & 0 & 31.3 \\
\hline
\end{tabular}

for the improved practices identified with $0 \%$ methane emission and scanty nitrous oxide emission up to $31.3 \%$. In addition, Table 5 indicates T2, T4 and T5 as satisfactory best treatments that have given significant responses to our different research objectives when compared to the rest of the treatments used and the farmers practice (control). Their SOCDG per month ranged from $167.5-284 \mathrm{~kg} / \mathrm{ha}$. Methane $\left(\mathrm{CH}_{4}\right)$ emission was zero $(0 \mathrm{~kg} / \mathrm{ha})$ and nitrous oxide $\left(\mathrm{N}_{2} \mathrm{O}\right)$ very scanty $(0.1-0.2 \mathrm{~kg} / \mathrm{ha})$. In contrast they have witnessed very high SOC sequestration potential $(1037.5 \mathrm{~kg} / \mathrm{ha})$ when compared to the rest of the treatments. Based on the aforesaid results, treatments T2, T4 and T5 can be identified as best improved practices to alleviate GHGs emissions from agricultural lands therefore, enhance their organic carbon pool for both mitigate climate change and increase croplands fertility in Northern West Nigeria especially Edozhigi rural community.

\section{CONCLUSION}

Findings from this study proffered more understanding and significant relevance of shortterm experiment on long-term monocropping croplands using pre-wetted straw and minimum urea application technique (improved technique). Moreover, results from this study were in accordance with the aforementioned objectives and research questions. It is obvious that, compared to the existing long-term experiment method, there is significant difference in terms of soil organic carbon density and soil organic carbon gained per month. High carbon input per month were observed with T4 $(284 \mathrm{~kg} / \mathrm{ha})$ followed by T2 $(222.5 \mathrm{~kg} / \mathrm{ha})$ and T5 (167.5 $\mathrm{kg} / \mathrm{ha}$ ) with lowest amount under the check plot $(68.5 \mathrm{~kg} / \mathrm{ha})$. Additionally, CCAFS-MOT indicates high carbon storage under T4, T2 and T5 up to $1037.5 \mathrm{~kg} / \mathrm{ha}$. All pre-wetted techniques used had indicated zero methane emission. However, Nitrous oxide was tiny $(0.1-0.2 \mathrm{~kg} / \mathrm{ha})$ under the control plot and treatments T4. T2 and T5. These results are promising and justify the need for its immediate implementation, recommendation and adoption as adequate sustainable agricultural land management practices under climate change events in Northern West Nigeria especially Edozhigi rural community.

\section{COMPETING INTERESTS}

Authors have declared that no competing interests exist.

\section{REFERENCES}

1. World Bank. Carbon foot-printing of ARD Projects: Testing the Ex-ante carbon balance appraisal tool. World bank, Washington, DC; 2012.

2. IPCC. Summary for Policymakers. In: Climate Change 2013: The Physical Science Basis. Contribution of Working Group I to the Fifth Assessment Report of the Intergovernmental Panel on Climate Change [Stocker, T.F., D. Qin, G.-K. Plattner, M. Tignor, S. K. Allen, J. Boschung, A. Nauels, Y. Xia, V. Bex and P.M. Midgley (eds.)]. Cambridge University Press, Cambridge, United Kingdom and New York, NY, USA; 2013.

3. Stockmann U, Adams MA, Crawford JW, Field DJ, Henakaarchchi N, Jenkins M. The knowns, known unknowns and unknowns of sequestration of soil organic carbon. Agriculture Ecosystems and Environment. 2013;164:80-99.

4. Lal R. Sequestering carbon in soils of arid ecosystems. Land Degradation and Development. 2009;454:441-454.

5. IPCC. Climate Change 2007: Mitigation of Climate Change of Working Groups III to the Fourth Assessment Report of the Intergovernmental Panel on Climate Change. Cambridge University Press, Cambridge, UK; 2007.

6. Lal R. Global potential of soil carbon sequestration to mitigate the greenhouse effect. Crit. Rev. Plant Sci. 2003;22(2): 151-184. 
7. Oelbermann M, Paul VR, Gordon AM. Carbon sequestration in tropical and temperate agroforestry systems: A review examples from Costa Rica and Southern Canada. Agriculture, Ecosystems and Environment. 2004;104(3):359-377.

8. Wang ZM, Zhang B, Song KS, Lui DW, Ren CY. Spatial variability of soil organic carbon under maize monoculture in the song-nen plain, Northeast China. Pedosphere. 2010;20(1):80-89.

9. Lal R. Sequestering carbon in soils of agroecosystems. Food policy. 2011;36: 533-539.

10. Bationo A, Buerkert A. Soil organic carbon management for sustainable land use in Sudano-Sahelian West African. Nutrient Cycling in Agroecosystems. 2001;61:131142.

11. World Bank. Carbon sequestration in agricultural soils. Report, Washington DC, USA; 2009.

12. Nielsen UN. Soil biodiversity and carbon cycling: a review and synthesis of studies examining diversity-function relationships. European Journal of Soil Science. 2011; 62(1):105-116.

13. Fuentes M, Govaerts B, Leon FD, Hidalgo C, Dendooven L, Sayre KE, Etchevers J. Fourteen years of applying zero and conventional tillage, crop rotation and residue management systems and its effect on physical and chemical soil quality. Europ. J. Agronomy. 2009;30:228-237.

14. Lal R. World crop residues production and implication of its use as a biofuel. Env Intl. 2005;31:575-586.

15. Liu Y, Yufang S, Shenjiao Y, Shiqing L, Fang C. Effect of mulch and irrigation practices on soil water, soil temperature and the grain yield of maize (Zea mays $L$ ) in Loess Plateau, China African J. of Agric.Res. 2011;6(10):2175- 2182.

16. Morisada K, Ono K, Kanomata H. Organic carbon stock in forest soils in Japan. Geoderma. 2004;119(1-2):21-32.

17. Jarecki Mk, Lal R. Compost and mulch effects on gaseous flux from an alfisol in ohio. Soil Sci. 2006;171:249-260.

18. Olaf E, Frederic L, Akande SO, Titilola SO, Akpokodje G, Ogundele OO. The Nigerian rice economy in a competitive world: Constraints, opportunities and strategic choices. Rice production systems in Nigeria: A survey. Warda, Abidjan, Côte d'Ivoire; 2003.
19. Obioha E. Climate change, population drift and violent conflict over land resources in North Eastern Nigeria. Journal of Human Ecology 2008;23(4):311-324.

20. Fasona MJ, Omojola SA. Climate Change Human Security and Communal Clashes in Nigeria. An International Workshop Holmen Fjord Hotel, Asker, near Oslo; 2005.

21. Akinro AO, Opeyemi DA, Ologunagba IB. Climate change and environmental degradation in the Niger Delta region of Nigeria: Its vulnerability, impacts and possible mitigations. Research Journal of Applied Sciences. 2008;167-173.

22. Ojeniyi S, Odedina J, Akinola M. Effect of tillage and mulch combination on soil physical properties and Sorghum performance on Alfisol of Southwset Nigeria. Nigeria J. of Soil Science. 2009;19 (9).

23. Christopher SF, Lal R. Nitrogen management affects carbon sequestration in North American croplands soils. CRC Crit. Rev. Plant Sci. 2007;26:45-64.

24. Jordan A, Zavala LM, Gil J. Effects of mulching on soil physical properties and run-off under semi-arid conditions in Southern Spain. Elsevier. 2010;81:77-85.

25. Nigerian Environmental Study/ Action Team (NEST) and Woodley, E. (Eds.). Reports of pilot projects in communitybased adaptation - climate change in Nigeria. Building Nigeria's Response to Climate Change (BNRCC). Ibadan, Nigeria; 2011.

26. Gwary D. Climate change, food security and Nigeria agriculture. Department of crop protection, University of Maiduguri, Nigeria; 2008.

27. Walkley A, Black IA. An experimentation of Degtjareff method for determining soil organic matter and a pro-posed modification of the chromic acid titration method. Soil Sci. 1934;37:29-38.

28. Konen ME, Jacobs PM, Burras BJ, Masson JA. Equation for predicting soil organic carbon using loss on ignition for north central U.S. soils. Sci. Soc. Am. J. 2002;66:1878-1881.

29. Schumacher BA. Methods for the determination of total organic carbon (TOC) in soils and sediments. Ecological Risk Assessment Support Center, Office of Research and Development. US Environmental Protection Agency. Las Vegas; 2002. 
30. Osenberg CW, Sarnelle O, Cooper SD, Holt RD. Resolving ecological questions through meta-analysis: Goals, metric and models. Ecology. 1999;80:1105-1117.

31. Zhu L, Yang M, Chen C. Effect of improved management practices on soil organic carbon sequestration in wheat-maize double cropping system in North China. J, of Agric. Sc. 2012;4(9).

32. Watson RT, Noble IR, Bolin B, Ravindranath $\mathrm{NH}$, Verado DJ, Dokken DJ. Land use, land use change, and forestry. Cambridge University Press, Cambridge, UK; 2000.

33. West TO, Six J. Considering the influence of sequestration duration and carbon saturation on estimates of soil carbon capacity. Clim Change. 2007;80:25-41.

34. Chan KY, Oates A, Lui DL, Li GD, Prangnell R, Poile G, Conyers M. A farmer's guide to increasing soil organic carbon under pastures, Industry \& Investment NSW, Wagga Wagga NSW; 2010.

35. Walcott J, Bruce S, Sims J. Soil carbon for carbon sequestration and trading: A review of issues for agriculture and forestry, Canberra; 2009.

36. Alluvione F, Halvorson AD, Del Gosso SJ. Nitrogen, tillage and crop rotation effects on carbon dioxide and methane fluxes from irrigated cropping systems. J. Environ 2009;38:2023-2033.

37. Reicosky DC, Archer DW. Moldbord plow tillage depth and short-term carbon dioxide release. Soil Tillage Res. 2007;94:109121.

38. Curtin D, Wang H, Selles F, McConkey BG, Campbell CA., 2000. Tillage effects on carbon fluxes in continuous wheat and fallow-wheat rotations. Soil Sci. Soc. Am. J. 2000;64:2080-2086.

39. Varughese MA. Mulching and tillage effects on GHG emissions and properties of an Alfisol in Central Ohio. Master's Thesis; 2011.

40. Rochette PH. No tillage only increases $\mathrm{N}_{2} \mathrm{O}$ emissions in poorly aerated soils. Soil Till Res. 2008;101:97-100.
41. Ussiri DAN, Lal R, Jarecki MK. Nitrous oxide and methane emissions from longterm tillage under a continuous corn cropping system in Ohio. Soil Till. Res. 2009;104:247-253.

42. Venterea RT, Burger M, Spokas KA. Nitrogen oxide and methane emissions under varying tillage and fertilizer management. Journal of Env. 2005;34: 1467-1477.

43. Wassmann, Neue RHU, Lantin RS, Buendia LV, Rennenberg $\mathrm{H}$. Characterization of methane emissions from rice fields in Asia. I. Comparison among field sites in five countries. Nutrient Cycling in Agroecosystems. Kluwer Academic Publishers. 2000;58:1-12.

44. Xiaoyuan Y, Kazuyuki Y, Hiroko A, Hajime A. Statistical analysis of the major variables controlling methane emission from rice fields. Global Change Biology. 2005;11:1131-1141.

45. Grandy AS, Loecke TD, Parr S, Robertson GP. Long term trends in nitrous oxide emissions, soil nitrogen, and crop yields of till and no-till cropping sys- tems. J. Environ. Qual. 2006;35:1487-1495.

46. Gregorich EG, Rochette P, St-Georges P, McKim UF, Chan C. Tillage effects on N2O emissions from soils under corn and soybeans in eastern Canada. Can. J. Soil Sci. 2008;88:153-161.

47. Ma J, Ma E, Xu H, Yagi K. Wheat straw management affects $\mathrm{CH}_{4}$ and $\mathrm{N}_{2} \mathrm{O}$ emissions from rice fields. Soil Biol. Biochem. 2009;41:1022-1028.

48. Snyder CS, Bruulsema TW, Jensen TL, Fixen PE. Review of greenhouse gas emissions from crop production systems and fertilizer management effects. Agric. Ecosyst. Envi. 2009;133:247-266.

49. Mutegi JK, Munkholm LR, Petersen BM, Hansen E.M, Petersen SO. Nitrous oxide emissions and controls as influenced by tillage and crop residue management strategy. Soil Biol. Biochem 2010;42:17011711.

(c) 2016 Koglo et al.; This is an Open Access article distributed under the terms of the Creative Commons Attribution License (http://creativecommons.org/licenses/by/4.0), which permits unrestricted use, distribution, and reproduction in any medium, provided the original work is properly cited.

Peer-review history:

The peer review history for this paper can be accessed here: http://sciencedomain.org/review-history/15779 